ISA

Arboriculture \& Urban Forestry 2016. 42(3): 160-169

\title{
Impact of Nursery Root Pruning and Tree Orientation at Planting on Growth and Anchorage
}

\author{
Edward F. Gilman, Maria Paz, and Chris Harchick
}

\begin{abstract}
Root pruning by shaving $12 \mathrm{~L}$ container root balls when shifting to $51 \mathrm{~L}$ containers did not impact Acer rubrum L. or Quercus virginiana Mill. root architecture within the top $12 \mathrm{~cm}$ of planted $51 \mathrm{~L}$ root balls five years later, despite marked differences at planting, and had no impact on tree height or trunk diameter increase. Root pruning in the nursery did not affect bending stress required to tilt Acer trunks up to five degrees (anchorage) either one, two, or three years after landscape planting. In contrast, anchorage was greater the second year after planting Quercus that were root pruned. Rotating trees 180 degrees at planting from their orientation in the nursery had no impact on Acer or Quercus anchorage, tree height, or trunk diameter. Rotating oak (not maple) trees 180 degrees at planting increased root cross-sectional area growing from the hot (south) side of the root ball when trees were rotated at planting.

Key Words. Acer rubrum; Anchorage; Bending Stress; Maple; Oak; Quercus virginiana; Root Ball Shaving; Root Morphology; Root Pruning; Winching.
\end{abstract}

Trees grown in containers develop root systems that are different from trees grown by other nursery production methods. Instead of spreading to their natural distance (Stout 1956; Watson and Himelick 1982), roots on shade trees are deflected up, down, or around by container walls (Harris and Gilman 1991), and this can affect post-landscape planting root architecture (Marshall and Gilman 1998). Roots growing away from the trunk can also be deflected 180 degrees and grow back to and close to the trunk (Fare 2005). Root systems of container-grown seedlings can develop poor symmetry with fewer main lateral roots after 12 years; naturally regenerated seedlings often have greater sinker root development, and can possess self-grafted roots (Halter et al. 1993).

Container dimensions, size, and container-wall porosity can change root architecture (Struve 1993; Arnold 1996; Marshall and Gilman 1998). Seedlings in porous-walled $5 \mathrm{~cm}$ diameter containers had fewer packed roots, fewer spiraling roots, and fewer L-shaped roots than those grown in solid-walled containers (Ortega et al. 2006). Root elongation on the periphery of the root ball can be stalled, at least for a time, by growing trees in containers coated with copper (Burdett 1978; Struve 1993; Gilman and Beeson
1995). Rooted cuttings in copper-treated containers had a greater percentage (40\%) of roots emerging from the top one-third of the plug, compared to trees grown in containers not treated with copper (18\%); there were also more roots on the interior of the root ball and fewer on the outside, forming a cage or imprint (Smith and McCubbin 1992). In contrast, Gilman and Beeson (1995) found no increase in root tips on the root ball interior for Ilex cassine $\mathrm{L}$.

Lateral roots were more evenly distributed throughout the root ball in mechanically pruned Pinus contorta (Dougl. Ex Loud) than in the solidwalled, untreated control (Krasowski 2003). The same was true for at least seven other temperate and tropical hardwood trees (Gilman et al. 2010b). Roots that emerged in the non-pruned, nontreated control after seedlings were installed in the field were located primarily at the bottom of the original plug; this was considered a defective root system, resulting in a less stable tree following planting into the field (Lindgren and Örlander 1978).

Root deformations caused by deflection in the propagation container can lead to poor rooting out, which results in unstable trees (Lindgren and Örlander 1978). For example, Scots pine (Pinus 
sylvestris L.) trees developed spiraling roots when in $75 \mathrm{ml}$ propagation containers, causing them to be less stable in the soil seven to nine years after planting compared to naturally regenerated trees (Lindström et al. 2005). Other root defects, such as downward-deflected roots, were later recognized as causing problems with stability following planting jack pine (Pinus banksiana Lamb. (Chapman and Colombo 2006). Many studies on conifer seedlings show that root deflection in propagation containers can contribute to long-term growth problems after planting in the forest (Krasowski 2003). Roots on shade trees in larger containers also deflect around or downward and proliferate at the bottom of containers (Gilman and Paz 2014) - probably because of suitable air, nutrition, and water at the bottom-but the impacts on health and anchorage are poorly documented.

Because straight, non-deflected roots appear to be associated with well-anchored trees planted into field soil from propagation (Salonius et al. 2000) and larger nursery (Gilman and Harchick 2014) containers, the main goal of the present study was to determine influence of root form in a container root ball on growth, root architecture, and anchorage, several growing seasons after planting into landscape soil. Specifically, the study authors wanted to determine the influence of shaving the periphery of a $12 \mathrm{~L}$ root ball when shifting into a $51 \mathrm{~L}$ nursery container on growth and anchorage several years after planting the $51 \mathrm{~L}$ root ball into the landscape. The secondary objective was to determine the importance of planting the imprinted (Gilman et al. 2010b) north side of the tree as it stood in the nursery toward the north in the landscape. Acer and Quercus were chosen due to their popularity as urban landscape trees in many temperate climates.

\section{MATERIALS AND METHODS}

\section{Trees and Landscape Planting}

On 29-30 April 2008, forty $12 \mathrm{~L}(30 \mathrm{~cm}$ tall $\times 26$ $\mathrm{cm}$ top diameter) cutting-propagated, containergrown (Airpot ${ }^{\mathrm{tm}}$, Caledonian Tree Company, Ltd., Scotland) 'Florida Flame' red maples (Acer rubrum L.) and 40 Cathedral Oak ${ }^{\oplus}$ live oaks (Quercus virginiana Mill. 'SDLN'), selected for trunk diameter uniformity from Cherry Lake Tree Farm in Grove- land, Florida, U.S., were shifted into 51 L solidwalled containers $(35 \mathrm{~cm}$ tall $\times 44 \mathrm{~cm}$ top diameter, Nursery Supplies, Inc., Chambersburg, Pennsylvania, U.S.) $112 \mathrm{~km}$ north in Gainesville, Florida, U.S. Trunk diameter averaged $16.8 \mathrm{~mm}(\mathrm{SD}=$ 1.8) for maples and $14.0 \mathrm{~mm}(\mathrm{SD}=1.5)$ for oaks, placing them well within standard size (American Association of Nurserymen 2014). Twenty trees of each taxa were root pruned by shaving (removing, Gilman et al. 2010a) about $3 \mathrm{~cm}$ from the root ball periphery and bottom before shifting. The other 20 trees were shifted without disturbing the root ball, acting as controls. After shifting into $51 \mathrm{~L}$ containers, the north side of the trunk was marked and always maintained toward the north while trees were in $51 \mathrm{~L}$ containers. Trees of each taxon were arranged on black woven nursery ground cloth in separate randomized complete block designs with one tree per treatment combination in each of 20 blocks. Each was irrigated three times daily, pruned to one leader, and staked in June 2008. In October (maples) 2008 and January 2009 (oaks), ten of the twenty blocks chosen at random (2 root pruning $\times 10$ replicates $=20$ trees) of each taxon were destructively harvested to measure root system attributes described in Gilman et al. (2010a).

Twenty trees remaining of each taxon ( 2 root pruning $\times 10$ replicate blocks $=20$ ) were planted into landscape soil in a field [Millhopper fine sand (loamy, siliceous, hyperthermic Grossarenic Paleudults)] with less than $2 \%$ organic matter and a bulk density of $1.51 \mathrm{~g} / \mathrm{cc}$ in USDA hardiness zone 8b in Gainesville, on 25-26 November 2008 (maples) and 6-7 January 2009 (oaks). Trunk diameter was $37 \mathrm{~mm}(\mathrm{SD}=2.6)$ for maples and $27 \mathrm{~mm}(\mathrm{SD}=1.9)$ for oaks, placing them well within standard size. The north mark on the trunk was placed either north or rotated 180 degrees south when field planting. This provided for two tree orientations: north in the nursery to north in the landscape, and north rotated to the south. Trees were in four rows $3.4 \mathrm{~m}$ apart. Holes 10 to $15 \mathrm{~cm}$ wider than the root balls were dug with straight sides and flat bottoms with height adjustment so the top of the undisturbed root ball was about even with the landscape soil surface. One person packed the bottom of holes by foot in an effort to standardize settling. No trees were root pruned when planted into the landscape. Once 
the root ball was placed in the planting hole a 15 $\mathrm{cm}$ wide volume of undisturbed soil at the edge of hole was pushed into the hole. The rest of the void around the root ball was filled with soil from the planting hole. Water was added to settle backfill soil and soil was lightly tamped by foot to standardize compaction of backfill soil. No berm or water ring was constructed around the root ball.

Chipped, whole branches and leaves from utility line clearance operations were applied as mulch $12 \mathrm{~cm}$ thick (before settling) $1.8 \mathrm{~m}$ wide within each of four rows. Trees were irrigated on the root ball three times a week and were fertilized under the crown with $200 \mathrm{~g}$ of $16-4-8\left(\mathrm{~N}-\mathrm{P}_{2} \mathrm{O}_{5}-\mathrm{K}_{2} \mathrm{O}\right)$ in March and June 2009, and $400 \mathrm{~g}$ of 20-0-8 $\left(\mathrm{N}^{-} \mathrm{P}_{2} \mathrm{O}_{5}-\right.$ $\mathrm{K}_{2} \mathrm{O}$ ) in March and May 2010, and March and June 2011 and 2012. Weeds were controlled in the mulch with periodic (three to four) annual applications of glyphosate (isopropylamine salt, 41\%); vegetation between rows was periodically mowed.

\section{Evaluating Post-Planting Anchorage and Growth}

To evaluate lateral tree stability (anchorage), trunks were pulled laterally with a winch in late August/early September 2009, 2010, and 2011 for maples, and October 2009, 2010, and 2011 for oaks. All trees were pulled (one or two blocks each rain-free day) with a steel cable and electric winch (Model 40764; Chicago Electric Power Tools, Inc., Camarillo, California, U.S.) in the 350 degree azimuth (from north) direction. There was no prevailing wind direction at the site. The winch attached to a cable about $1.2 \mathrm{~m}$ from the ground remained parallel to ground. A $3,629 \mathrm{~kg}$ capacity load cell (SSM-AF-8000; Interface Inc., Scottsdale, Arizona, U.S.) was placed in-line with the winching cable. An inclinometer (model N4; Rieker Inc., Aston, Pennsylvania, U.S.) was mounted to a fabricated steel plate $(5.1 \mathrm{~cm} \times 7.6$ $\mathrm{cm})$. The plate was secured to the trunk $15 \mathrm{~cm}$ from soil surface, which was just above the swollen flare. The cable was winched at $2 \mathrm{~cm} \bullet \mathrm{sec}^{-1}$ until the inclinometer tilted five degrees from vertical start position; then the cable was released.

Data from load cell and inclinometer were collected at $2 \mathrm{~Hz}$ by Data Acquisition System (National Instruments Corporation, Austin, Texas, U.S.). Data from pulling tests were displayed in real time on a laptop running LabView software (v: 7.0; National Instruments, Austin, Texas, U.S.). Trunk bending stress was calculated according to Equation 1:

$$
\text { [1] } \quad \sigma=\frac{F \cdot d \cdot R}{\frac{\pi}{4} \cdot R^{4}}
$$

where $\sigma=$ bending stress

$\mathrm{F}=$ pulling force

$\mathrm{d}=$ distance from pulling point to inclinometer

$\mathrm{R}=$ trunk radius (calculated as halving diameter measured with a diameter tape)

Trunk diameters at $15 \mathrm{~cm}$ from ground and tree height were measured at planting and in September of each year through 2013. In May 2014, soil was removed with high-speed air in a $40 \mathrm{~cm}$ radius around the trunk to expose the top $12 \mathrm{~cm}$ of the original $51 \mathrm{~L}$ root ball. Measurements included diameter of the five largest roots $10 \mathrm{~cm}$ beyond edge of the $51 \mathrm{~L}$ container in the top $12 \mathrm{~cm}$ of soil profile on the north and south 180 degree circumference of the tree (total 10 roots on each tree). Root diameter was measured from the top of the root to the bottom and perpendicular to that, and these were averaged to calculate the cross-sectional area (CSA) of a circle on the ten roots on each tree. Visual root system imprint $(1=$ little imprint with mostly straight roots; $5=$ strong imprint, many roots deflected by and retaining the shape of the container) caused by roots deflected by the 12 $\mathrm{L}$ or $51 \mathrm{~L}$ container walls was rated for each tree.

\section{Experimental Design and Statistical Analysis}

Trees in $51 \mathrm{~L}$ containers were placed on nursery ground cloth in a randomized complete block design described in Gilman et al. (2010b). Trees of both taxa were planted into landscape soil in a randomized complete block design with 2 taxa $\times$ 2 root prunings $\times 2$ tree orientations $\times 5$ blocks $=$ 40 trees. Taxa were statistically analyzed separately. Main effects on trunk tilt from root pruning and tree orientation were analyzed in the GLM procedure of SAS (1992) with repeated measures twoway analysis of variance (ANOVA); main effects on root CSA from root pruning, tree orientation, and side of the trunk (north or south) were analyzed with three-way ANOVA. Means were separated 
with Tukey's multiple range test; interaction means were compared using LSD. Stepwise procedure in SAS (1992) calculated regression coefficients.

\section{RESULTS AND DISCUSSION}

Root pruning $12 \mathrm{~L}$ container root balls as they were shifted to $51 \mathrm{~L}$ containers in the nursery did not impact mean trunk diameter $(37 \mathrm{~mm}$, maple; $27 \mathrm{~mm}$, oak) or tree height (3.4 m, maple; $2.4 \mathrm{~m}$, oak) at landscape planting (Gilman et al. 2010b). This also held true after planting into the landscape (data not shown). For example, nursery root pruning had no effect on mean tree height increase ( $4.6 \mathrm{~m}, P=0.69$, maple; $5.0 \mathrm{~m}, \mathrm{P}=0.93$, oak) through 2012 (four years after planting) or mean trunk diameter increase $(121 \mathrm{~mm}, P=0.27$, maple; $132 \mathrm{~mm}, P=0.73$, oak) through 2013 (five years after planting). Changing tree orientation at planting-by rotating trees 180 degrees compared to their orientation in the nursery-also had no influence on tree height or trunk diameter increase for either taxon in any year after landscape planting $(P>0.73)$. There was no trunk bark damage evident on any trees at any time.

There was no impact $(P>0.42)$ of root pruning in nursery containers or tree orientation when planting into the landscape on root system imprint rating (from $12 \mathrm{~L}$ or $51 \mathrm{~L}$ containers) five years later on either taxon (data not shown). This occurred despite significant root architecture differences at planting-due to root pruning during nursery production (Gilman et al. 2010b) - and appears to suggest that deflections from container walls occurring five years previously did not persist and did not result in the potential, long-term health issues caused by roots circling the trunk. This might be attributed to the short duration in $12 \mathrm{~L}$ (14 months) and $51 \mathrm{~L}$ containers (seven months) prior to landscape planting; whereas trees are often retained for much longer by many growers (personal observation) even as they remain in conformance with industry standard sizes (American Association of Nurserymen 2014). A longer retention time for these and other taxa would likely have resulted in a greater container imprint on the root system as others found (Salonius et al. 2000; Gilman et al. 2012). Moreover, the type of $12 \mathrm{~L}$ container used in this study has been shown to reduce root system imprint and length of roots circling the container compared to smooth-sided containers (Gilman et al. 2010a). In addition, both taxa were propagated from cuttings, and there is evidence that each taxa continues forming new roots from the root collar when planted from 12 L into larger containers (Gilman and Harchick 2008, oaks; Gilman et al. 2013, maples). Continued new root production within the $51 \mathrm{~L}$ container may have allowed both to mostly outgrow the $12 \mathrm{~L}$ container imprint by generating new roots that became larger than those deflected by the smaller container. Results would likely be different for species that cease producing new roots from the root collar soon after seed germination, such as Tabebuia spp. (Gilman et al. 2010b).

Arborists and other practitioners report that stem-girdling roots in the landscape are a direct result of roots circling in nursery containers, and these can cause trees to become physiologically stressed or worse in the landscape (Giblin et al. 2005). Perhaps surprisingly, there is sparse documentation in the scientific literature of containerinduced root deflections causing health issues in the landscape, although there is ample evidence that conifers planted from propagation containers in reforestation efforts can perform poorly when planted with root defects (Burdett 1978; Salonius et al. 2000). In related work, Tate (1980) and Giblin et al. (2005) showed that encircling roots in the landscape-typically attributed to planting too deeply-can cause a decline in health as long as three decades later. However, these roots could have been generated after planting and been the result of site conditions or other factors not inherent to the nursery stock. Arborists also report poor anchorage on trees with severe circling roots and other root defects from the nursery (Johnson and Hauer 2002); Gilman and Masters (2010) documented that some of the reported instability is directly attributed to root architecture created in the nursery and other factors.

Root pruning during production did not impact bending stress required to tilt maple trunks one to five degrees in either one $(P>0.19)$, two $(P>$ $0.84)$, or three $(P>0.84)$ years after landscape planting (Table 1). Tree orientation at planting also had no impact on maple bending stress in the first three years after landscape planting - the only years tested (Table $1, P>0.17$ ). Lack of impact on post-planting maple anchorage from either main 
effect came despite significant pruning-induced changes in root architecture (i.e., smaller container imprint) within the root ball at planting five years earlier (Gilman et al. 2010b). No main effects (root pruning, tree orientation, side of tree) influenced maple root CSA; however, root pruning inexplicably reduced root CSA in the five largest roots when maple trees were rotated 180 degrees at planting but had no impact when trees were planted in their nursery orientation (Table 2).

Similarity in maple anchorage between treatments in the current study could have been due to the relatively small size of the trees $(16 \mathrm{~mm}$ trunk diameter) in the $12 \mathrm{~L}$ containers prior to shifting into $51 \mathrm{~L}$ containers compared to a recent study on slightly older trees of the same maple $(20 \mathrm{~mm}$ trunk diameter in $12 \mathrm{~L}$ container, Gilman et al. 2016) that showed better anchorage after planting of nursery stock that was root pruned when shifted to larger containers. Trees retained in containers for a longer period have more root defects with a greater root system imprint than those retained for a shorter period, leading to a smaller amount of roots growing into substrate or soil after planting (Salonius et al. 2000). Root pruning by shaving older propagation container root balls that were more imprinted had a greater impact on root architecture within $12 \mathrm{~L}$ root balls than shaving less pot-bound trees (Gilman et al. 2012).

Like maples, root pruning during nursery production did not impact bending stress required to tilt oak trunks one to three degrees at the end of the first or third year after planting $(P>0.75$, Table 3). Unlike maples, at the end of the second growing season, there was a significant root pruning effect on bending stress required to winch oaks to all angles $(P<0.03$; Table 3 and Figure 1$)$. Specifically, shaving $12 \mathrm{~L}$ container root balls as they were shifted into $51 \mathrm{~L}$ containers resulted in about a $28 \%$ increase in bending stress required to tilt oaks five degrees (Figure 1); this indicated better anchorage. There are few other studies evaluating post-planting anchorage of trees root pruned during nursery production. Gilman et al. (2016) found that planting $57 \mathrm{~L}$ (similar size as current study) or $170 \mathrm{~L}$ red maple root balls that were shaved in the nursery improved anchorage in the landscape by $20 \%-25 \%$ compared to trees not shaved. Improved anchorage in that study was attributed to an abundance of straight roots

Table 1. Bending stress required to winch maple trunk base to increasing angles one, two, and three years after planting.

\begin{tabular}{|c|c|c|c|c|c|c|}
\hline \multirow{2}{*}{$\begin{array}{l}\text { Years after } \\
\text { planting }\end{array}$} & \multirow[t]{2}{*}{ Source of variation } & \multicolumn{5}{|c|}{ Trunk tilt (degrees from vertical start position) } \\
\hline & & \multicolumn{5}{|c|}{ Bending stress $\mathrm{MN} / \mathrm{m}^{2}(P$-value $)$} \\
\hline One & $\begin{array}{l}\text { Root pruning } z \\
\text { Tree orientation }\end{array}$ & $\begin{array}{l}7.6 \\
(0.19) \\
(0.68)\end{array}$ & $\begin{array}{l}12.1 \\
(0.24) \\
(0.82)\end{array}$ & $\begin{array}{l}15.0 \\
(0.40) \\
(0.80)\end{array}$ & $\begin{array}{l}17.1 \\
(0.45) \\
(0.45)\end{array}$ & $\begin{array}{l}19.3 \\
(0.68) \\
(0.29)\end{array}$ \\
\hline Two & $\begin{array}{l}\text { Root pruning }{ }^{z} \\
\text { Tree orientation }\end{array}$ & $\begin{array}{l}12.1 \\
(0.84) \\
(0.21)\end{array}$ & $\begin{array}{l}18.2 \\
(0.91) \\
(0.17)\end{array}$ & $\begin{array}{l}22.4 \\
(0.94) \\
(0.31)\end{array}$ & $\begin{array}{l}25.7 \\
(0.97) \\
(0.43)\end{array}$ & $\begin{array}{l}28.3 \\
(0.86) \\
(0.70)\end{array}$ \\
\hline Three & $\begin{array}{l}\text { Root pruning } \\
\text { Tree orientation }\end{array}$ & $\begin{array}{l}10.7 \\
(0.91) \\
(0.57)\end{array}$ & $\begin{array}{l}16.6 \\
(0.84) \\
(0.48)\end{array}$ & $\begin{array}{l}21.0 \\
(0.87) \\
(0.63)\end{array}$ & $\begin{array}{l}24.3 \\
(0.84) \\
(0.74)\end{array}$ & $\begin{array}{l}27.0 \\
(0.84) \\
(0.85)\end{array}$ \\
\hline
\end{tabular}

${ }^{2} P$-value comparing root pruned (by shaving off about $3 \mathrm{~cm}$ of the periphery) $12 \mathrm{~L}$ root ball as it was shifted into $51 \mathrm{~L}$ containers with those not root pruned. ${ }^{y} P$-value comparing trees planted in the same azimuth orientation as grown in the nursery with those rotated 180 degrees from orientation in nursery at planting (i.e., north facing side turned to the south).

Note: Interactions not significant $(P>0.25)$.

Table 2. Effect of tree orientation at planting on maple root growth five growing seasons after planting.

\begin{tabular}{lll}
\hline $\begin{array}{l}\text { Root pruning } \\
\text { in nursery }\end{array}$ & $\begin{array}{l}\text { Tree orientation: north side } \\
\text { in nursery planted to the: }\end{array}$ & $\begin{array}{l}\text { Total CSA five largest roots in } \\
\text { top } 12 \mathrm{~cm} \text { soil profile }\left(\mathrm{mm}^{2}\right)\end{array}$ \\
\hline Yes & $\begin{array}{l}\text { South in landscape } \\
\text { North in landscape }\end{array}$ & $2003 \mathrm{~b}^{\mathrm{z}}$ \\
& $5312 \mathrm{a}$ \\
No & South in landscape & $3511 \mathrm{ab}$ \\
& North in landscape & $3538 \mathrm{ab}$ \\
\hline
\end{tabular}

${ }^{z}$ Means within columns with a different letter are statistically different at $P<0.06 ; \mathrm{n}=5$. 
in the root ball. This has been accomplished by shaving when shifting to a larger container size in the nursery, or by growing in certain porouswalled containers (Gilman and Paz 2014).

In slight contrast to maples, oak tree orientation at planting affected $(P=0.06)$ bending stress required to tilt trunks at the end of the first year after planting, but only to four and five degrees (Table 3) and not in the second and third growing seasons. Specifically, rotating the north side of oaks 180 degrees to the south when planting into the landscape resulted in about a 15\% decrease in anchorage when winched north to four and five degrees trunk tilt, compared to maintaining trees in the same orientation as in the nursery at planting (Table 4). Oak trees rotated at planting had nearly five times the root CSA $\left(3,485 \mathrm{~mm}^{2}\right.$, averaged across root pruning) on the north side of the tree measured five growing seasons after planting than those not rotated at planting (776 $\mathrm{mm}^{2}$; Table 5). Although this indicated more growth from the hot (south) side of the container, trees not rotated at planting failed to show this response. This makes definitive conclusions on the impact of orientation in the nursery container on post-planting root growth difficult. There is evidence of reduced root growth on the periphery of the hot side of nursery containers (Ruter 1993), resulting in smaller diameter and fewer roots (Gilman et al. 2016) that can position more root tips within the root ball (Smith and McCubbin 1992) capable of growing out into landscape soil. An increase in root CSA outside the root ball could eventually contribute to anchorage by entrapping a larger volume-and therefore mass-of soil in the root plate to resist overturning (Fourcaud et al. 2007; Gilman and Masters 2010).

Stability in forest plantations has been associated with shallow roots in the windward direction (Stokes 1999), lateral roots positioned symmetrically around the trunk (Coutts et al. 1999), tap and sinker root mass (Danjon et al. 2005), leeward sinker root length (Hayfa et al. 2007), and combinations of these. There is far less known about the anchorage of trees planted from landscape-sized root balls, and results vary even for similar taxa. For example, root CSA measured toward the pulling winch three years after landscape planting of four-year-old Quercus virginiana Cathedral Oak from $170 \mathrm{~L}$ containers (Gilman and Masters 2010) has been associated with anchorage; whereas root CSA on the opposite side of the tree was most correlated with anchorage for a different cultivar of the same species ( $Q$. virginiana Highrise ${ }^{\circledast}$ ) planted from 57 L containers (Gilman and Weise 2012). Experimental design did not allow roots to be measured when trees were winched, making

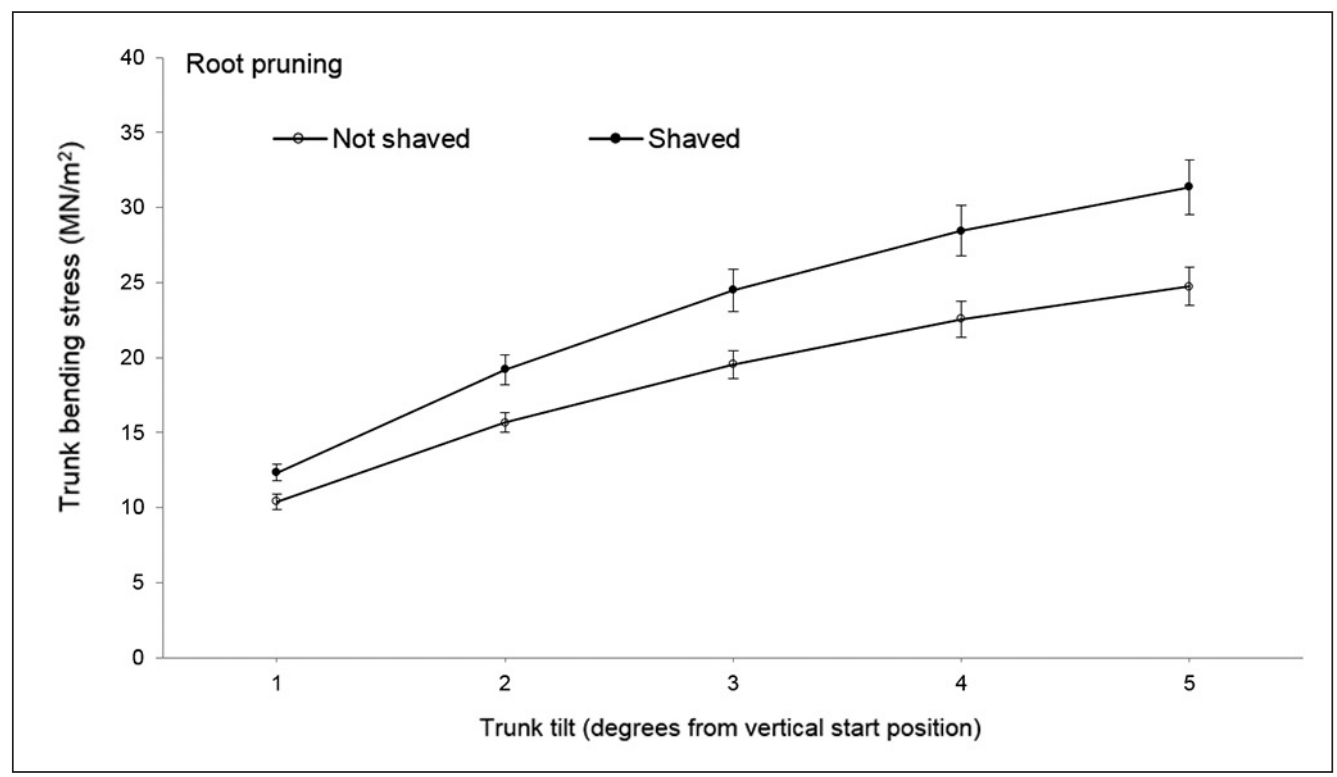

Figure 1. Effect of root pruning in nursery on trunk bending stress to winch oak two growing seasons (21 months, October 2010; $P=0.03$ ) after planting into field soil; vertical lines represent SE. 
direct relationships between root attributes and anchorage difficult; however, there were some correlations. Maple and oak bending stress to tilt trunks three years after planting was positively correlated with root CSA in the largest five roots in the north and south sides of the tree measured five years after planting (Equation 2; Equation 3 ). Only about $20 \%$ of the variability in trunk tilt could be explained by root CSA. This significant but weak relationship suggests that although the CSA of the largest roots bridging the interface of container substrate and landscape soil play a role in anchoring trees in the first few years after planting, there are other factors involved. Future studies should excavate and characterize entire root systems-not just the top $12 \mathrm{~cm}$, as in the current study-in an effort more comprehensively quantify anchorage. Results could have been different if trees were retained in containers longer, if porous-walled containers were used, or if trees were planted in a different season.

[2] Bending stress $\left(\mathrm{MN} / \mathrm{m}^{2}\right)$ at five degrees maple trunk tilt winched north $=29.3+0.0003$ (CSA five largest roots north + five largest roots south); $P=0.05, \mathrm{R}^{2}=$ $0.21, \mathrm{n}=20$.

[3] Bending stress $\left(\mathrm{MN} / \mathrm{m}^{2}\right)$ at five degrees oak trunk tilt $=37.0+0.001(\mathrm{CSA}$ five largest roots north + five largest roots south); $P=0.05, \mathrm{R}^{2}=0.19, \mathrm{n}=20$.

Table 3. Bending stress required to winch oak trunk base to increasing angles one, two, and three growing seasons after planting.

\begin{tabular}{|c|c|c|c|c|c|c|}
\hline \multirow{3}{*}{$\begin{array}{l}\text { Years after } \\
\text { planting }\end{array}$} & \multirow[t]{3}{*}{ Source of variation } & \multicolumn{5}{|c|}{ Trunk tilt (degrees from vertical start position) } \\
\hline & & 1 & 2 & 3 & 4 & 5 \\
\hline & & \multicolumn{5}{|c|}{ Bending stress $\mathrm{MN} / \mathrm{m}^{2}$ ( $P$-value $)$} \\
\hline \multirow[t]{3}{*}{ One } & & 5.8 & 9.5 & 12.7 & 15.3 & 17.5 \\
\hline & Root pruning ${ }^{\mathrm{z}}$ & $(0.88)$ & $(0.90)$ & $(0.75)$ & $(0.15)$ & $(0.14)$ \\
\hline & Tree orientation ${ }^{y}$ & $(0.97)$ & $(0.89)$ & $(0.33)$ & $(0.06)$ & $(0.06)$ \\
\hline \multirow[t]{3}{*}{ Two } & & 11.4 & 17.4 & 22.0 & 25.5 & 28.0 \\
\hline & Root pruning ${ }^{z}$ & $(0.03)$ & $(0.03)$ & $(0.02)$ & $(0.02)$ & $(0.02)$ \\
\hline & Tree orientation ${ }^{y}$ & $(0.61)$ & $(0.89)$ & $(0.50)$ & $(0.42)$ & $(0.37)$ \\
\hline \multirow[t]{3}{*}{ Three } & & 12.6 & 20.2 & 25.5 & 29.2 & 31.9 \\
\hline & Root pruning ${ }^{z}$ & $(0.15)$ & $(0.07)$ & $(0.07)$ & $(0.08)$ & $(0.09)$ \\
\hline & Tree orientation ${ }^{y}$ & $(0.20)$ & $(0.33)$ & $(0.54)$ & $(0.68)$ & $(0.77)$ \\
\hline
\end{tabular}

${ }^{\mathrm{z}} \mathrm{P}$-value comparing root pruned (by shaving off 2 to $3 \mathrm{~cm}$ of the periphery) $12 \mathrm{~L}$ root ball as it was shifted into $51 \mathrm{~L}$ containers with those not root pruned.

${ }^{y} P$-value comparing trees planted in the same compass orientation as grown in the nursery with those rotated 180 degrees from orientation in nursery at planting

(i.e., north facing side turned to the south).

Note: Interactions not significant $(P>0.27)$.

Table 4. Effect of tree orientation on bending stress to winch oak trunks north one growing season (2009) after planting.

\begin{tabular}{lll}
\hline $\begin{array}{l}\text { Tree orientation: north side } \\
\text { in nursery planted to the: }\end{array}$ & $\begin{array}{l}\text { Trunk bending stress to four } \\
\text { degrees trunk tilt }\left(\mathrm{MN} / \mathrm{m}^{2}\right)\end{array}$ & $\begin{array}{l}\text { Trunk bending stress to five } \\
\text { degrees trunk tilt }\left(\mathrm{MN} / \mathrm{m}^{2}\right)\end{array}$ \\
\hline $\begin{array}{l}\text { North in landscape } \\
\text { South in landscape }\end{array}$ & $16.6 \mathrm{a}^{\mathrm{y}}$ & $18.8 \mathrm{a}$ \\
$14.2 \mathrm{~b}$ & $\mathrm{~b}$ \\
\hline
\end{tabular}

${ }^{z}$ There was no effect $(P>0.20)$ two and three growing seasons after planting.

${ }^{y}$ Means within columns with a different letter are statistically different at $P=0.06 ; \mathrm{n}=10$, averaged over root pruning. Winching up to three degrees in 2009 was not significant.

Table 5. Effect of tree orientation at planting and side of tree on oak root growth five growing seasons after planting.

\begin{tabular}{|c|c|c|}
\hline $\begin{array}{l}\text { Tree orientation: north side } \\
\text { in nursery planted to the: }\end{array}$ & $\begin{array}{l}\text { Side of the tree (north or south } \\
180 \text { degree circumference) }\end{array}$ & $\begin{array}{l}\text { Total CSA of five largest roots in top } \\
12 \mathrm{~cm} \text { soil profile }\left(\mathrm{mm}^{2}\right)\end{array}$ \\
\hline South in landscape & $\begin{array}{l}\text { North } \\
\text { South }\end{array}$ & $\begin{array}{l}3,485 \mathrm{a}^{\mathrm{z}} \\
1,057 \mathrm{~b}\end{array}$ \\
\hline North in landscape & $\begin{array}{l}\text { North } \\
\text { South }\end{array}$ & $\begin{array}{l}776 \mathrm{~b} \\
1,853 \mathrm{ab}\end{array}$ \\
\hline
\end{tabular}

${ }^{\mathrm{z}}$ Means within columns with a different letter are statistically different at $P<0.001 ; \mathrm{n}=5$, averaged over root pruning due to insignificant interaction. 


\section{CONCLUSIONS}

Oak and maple trunk diameter and tree height growth in the five growing seasons after planting were not impacted by rotating trees 180 degrees from their orientation in the nursery. Rotating trees 180 degrees at planting also had little impact on anchorage for either taxa the first three years after planting. Root pruning by mechanically shaving the periphery of the root ball as $12 \mathrm{~L}$ containers were shifted to $51 \mathrm{~L}$ containers reduced occurrence of root defects at the $12 \mathrm{~L}$ container position on finished $51 \mathrm{~L}$ nursery stock of both taxa (Gilman et al. 2010b) without impacting trunk or height growth (one to five growing seasons) or tree anchorage (one to three growing seasons) after planting into the landscape. Root pruning in the nursery improved oak anchorage only in the second growing season after landscape planting (not in the first or third). Oak (not maple) roots measured in the top $12 \mathrm{~cm}$ of soil grew substantially more in the five growing seasons after landscape planting from the side of the container that faced south in the nursery than from the side facing the north, but only on trees rotated 180 degrees at planting from their orientation in the nursery.

Acknowledgments. Thanks to innumerable nurseries in Florida, U.S., for provided financial support for this research.

\section{LITERATURE CITED}

American Association of Nurserymen. 2014. American standards for nursery stock. ANSI Z60.1-2004. American Association of Nurserymen, Washington D.C., U.S.

Arnold, M.A. 1996. Mechanical correction and chemical avoidance of circling roots differentially affect post-transplant root regeneration and field establishment of container-grown Shumard oak. Journal American Society Horticultural Science 121:258-263.

Burdett, A.N. 1978. Control of root morphogenesis for improved mechanical stability in container-grown lodgepole pine. Canadian Journal Forest Research 8:483-486.

Chapman, K.A., and S.J. Colombo. 2006. Early root morphology of jack pine seedlings grown in different types of container. Scandinavian Journal Forestry Science 21:372-370.

Coutts, M.P., C.C.N. Nielson, and B.C. Nicoll. 1999. The development of symmetry, rigidity, and anchorage in the structural root system of conifers. Plant and Soil 217:1-15.

Danjon F., T. Fourcaud, and D. Bert. 2005. Root architecture and wind-firmness of mature Pinus pinaster. New Phytology $168: 387-400$

Fare, D. 2005. Should potting depth be a concern for container trees? Proceedings of Trees and planting: Getting the roots right conference. 10 November 2005. The Morton Arboretum, Lisle, Illinois, U.S.
Fourcaud, T., J. Ji, Z. Zhang, and A. Stokes. 2007. Understanding the impact of root morphology on overturning mechanisms: A modeling approach. Annals of Botany 100:1093.

Giblin C., J. Gillman, D. Hanson, G. Johnson, and P. Weicherding. 2005. The effects of soil depth on the long-term health and frequency off storm damage to trees in the upper midwest. Proceedings of Trees and Planting: Getting the Roots Right. 10 November 2005. The Morton Arboretum, Lisle, Illinois, U.S.

Gilman, E.F., and C. Harchick. 2008. Planting depth in containers affects root form and tree quality. Journal of Environmental Horticulture 26:129-134.

Gilman, E.F., and C. Harchick. 2014. Root system morphology influences lateral stability of Swietenia mahagoni. Arboriculture \& Urban Forestry 40:27-35.

Gilman, E.F., and C. Wiese. 2012. Root pruning at planting and planting depth in the nursery impact root system morphology and anchorage. Arboriculture \& Urban Forestry 38:229-236.

Gilman, E.F., and F. Masters. 2010. Effect of tree size, root pruning and production method on root growth and lateral stability of Quercus virginiana. Arboriculture \& Urban Forestry 36: 281-291.

Gilman, E.F., and M. Paz. 2014. Root system morphology influenced by container design, retention time, and root pruning. Arboriculture \& Urban Forestry 40:16-26.

Gilman, E.F., and R.J. Beeson. 1995. Copper hydroxide affects root distribution of Ilex cassine in plastic containers. HortTechnology 5:48-49.

Gilman, E.F., C. Harchick, and M. Paz. 2010a. Effect of container type on root form and growth of red maple Journal Environmental Horticulture 28:1-7.

Gilman, E.F., J. Miesbauer, C. Harchick, and R.C. Beeson. 2013. Impact of tree size at planting, mulch, and irrigation on Acer rubrum L. growth and anchorage. Arboriculture \& Urban Forestry 39:173-181.

Gilman, E.F., M. Paz, and C. Harchick. 2010b. Root ball shaving improves root systems on seven species in containers. Journal of Environmental Horticulture 28:13-18.

Gilman, E.F., M. Paz, and C. Harchick. 2016. Effect of eight container types and root pruning during nursery production on root architecture of Acer rubrum. Arboriculture \& Urban Forestry 42(1):31-45.

Gilman, E.F., M. Paz, D. Meador, and P. Fischer. 2012. Propagation container type, time in pot, and roots pruning affect root development of young Acer rubrum. Journal of Environmental Horticulture 30:150-160.

Halter, M.R., C.P. Chanway, and G.J. Harper. 1993. Growth reduction and root deformation of containerized lodgepole pine saplings 11 years after planting. Forest Ecology Management 56:131-146.

Harris, J.R., and E.F. Gilman. 1991. Production system affects growth and root regeneration of Leyland cypress, laurel oak, and slash pine. Journal of Arboriculture 17:64-69.

Hayfa, K., A. Stokes, F. Danjon, K. Gouskou, and F. Lagane. 2007. Is it possible to manipulate root anchorage in young trees? Plant and Soil 294:87-102.

Impacts on trees, symptomology, and prevention. University of Minnesota. <www.extension.umn.edu/garden/yard-garden/treesshrubs/practitioners-guide-to-stem-girdling-roots> 
Johnson, G.R., and R. Hauer. 2002. A practitioner's guide to stem girdling roots of trees:Krasowski, M.J. 2003. Root system modifications by nursery culture reflect on post-planting growth and development of coniferous seedlings. Forestry Chronicle 79:882-891.

Lindgren O., and G. Örlander. 1978. A study on root development and stability of 6 to 7 -year old container plants. pp. 142-144. In: E. Van Eerden and J.M. Kinghorn (Eds.). Proc. of the Root Form of Planted Trees Symp., Victoria, BC, Canada. 16-19 May 1978. Canadian Forest Service, B.C., Joint Report No. 8.

Lindström, A., C. Hellqvist, and E. Stattin. 2005. Mini Seedlings-A New Forest Regeneration System. pp. 56-58. In: The Thin Green Line: A symposium on the state-of-the-art in reforestation. Ontario Forest Research Institute, Ontario Ministry of Natural Resources, 1235 Queen Street East Sault Ste. Marie, Ontario, Canada.

Marshall, M.D., and E.F. Gilman. 1998. Effects of nursery container type on root growth and landscape establishment of Acer rubrum L. Journal of Environmental Horticulture 16:55-59.

Ortega, U., J. Majada, A. Mena-Petite, J. Sanchez-Zabala, N. Rodriguez-Itturrizar, K. Txarterina, J. Azpitarte, and M. Duñabeitia. 2006. Field performance of Pinus radiata D. Don produced in nursery with different types of containers. New Forests 31:97-112.

Ruter, J.M. 1993. Growth and landscape performance of three landscape plants produced in conventional and pot-in-pot productions systems. Journal of Environmental Horticulture 11:124-127.

Salonius, P., K. Beaton, and B. Roze. 2000. Effects of cell size and spacing on root density and field performance of containerreared black spruce. Information Report M-X-208E, Canadian Forest Service, Atlantic Forestry Centre, Frederickton, New Brunswick, Canada.

SAS Institute, Inc. 1992. SAS/STAT users guide, version 9.1.3. SAS Institute, Inc., Cary, North Carolina, U.S.

Smith, I.E., and P.D. McCubbin. 1992. Effect of copper tray treatment on Eucalyptus grandis (Hill Ex Maiden) seedling growth. In: M. Hayashi, A. Kano, and E. Goto (Eds.). International Symposium on transplant production systems. Acta Horticulture 319.

Stokes, A. 1999. Strain distribution during anchorage failure of Pinus pinaster Ait. at different ages and tree growth response to wind-induced root movement. Plant and Soil 217:17-27.

Stout, B.B. 1956. Studies of the root systems of deciduous trees. Black Forest Bulletin 15. Cornwall-on-the-Hudson, New York: Harvard University 45 pp.

Struve, D.K. 1993. Effect of copper-treated containers on transplant survival and regrowth of four tree species. Journal of Environmental Horticulture 11:196-199.

Tate, R.L. 1980. Detection, description and treatment of girdling roots on urban Norway maple trees. Ph.D. Thesis, University of Michigan.

Watson, G.W., and E.B. Himelick. 1982. Root distribution of nursery trees and its relationship to transplanting. Journal of Arboriculture 8:305-310.

\author{
Edward F. Gilman (corresponding author) \\ University of Florida \\ Environmental Horticulture \\ 1533 Fifield Hall \\ Gainesville, Florida 32611, U.S. \\ egilman@ufl.edu \\ Maria Paz \\ University of Florida \\ Environmental Horticulture \\ 1533 Fifield Hall \\ Gainesville, Florida 32611, U.S. \\ Chris Harchick \\ University of Florida \\ Environmental Horticulture \\ 1533 Fifield Hall \\ Gainesville, Florida 32611, U.S.
}


Résumé. La taille des racines périphériques de mottes lors du transfert de contenants de $12 \mathrm{~L}$ dans des contenants de $51 \mathrm{~L}$ n'a eu aucun impact sur l'architecture racinaire des Acer rubrum $L$. ou des Quercus virginiana Mill. dans les 12 premiers centimètres des mottes transplantées dans les contenants de $51 \mathrm{~L}$ cinq ans plus tard, et ce, en dépit de différences marquées à la plantation, et n'a eu aucun impact sur la hauteur des arbres ou sur l'augmentation en diamètre des troncs. La taille des racines en pépinière n'a pas affecté la contrainte de flexion requise pour incliner jusqu'à cinq degrés (ancrage) les troncs des Acer que ce soit une, deux ou trois années après la plantation définitive. À l'inverse, l'ancrage était supérieur la deuxième année suivant la plantation pour les Quercus qui avaient fait l'objet d'une taille des racines. La rotation de 180 degrés des arbres à la plantation par rapport à leur orientation en pépinière n'a eu aucun impact sur l'ancrage des Acer ou des Quercus, ni sur la hauteur des arbres ou sur le diamètre du tronc. La rotation de 180 degrés des chênes (mais pas les érables) lors de la plantation a augmenté la surface terrière des racines croisant du côté le plus exposé au soleil (sud) de la motte.

Zusammenfassung. Der Wurzelrückschnitt in Form von einer Rasur eines 121 Containerwurzelballens bei der Verpflanzung in 51 1 Container hatte innerhalb der oberen $12 \mathrm{~cm}$ des 511 Containers nach fünf Jahren keinen Einfluss auf die Wurzelarchitektur bei Acer rubrum oder Quercus virginiana, trotz bemerkter Unterschiede während der Pflanzung und es hatte keinen Einfluss auf die Baumhöhe oder Stammdurchmesserzuwachs. Der Wurzelschnitt in der Baumschule hatte keinen Einfluss auf den Stress, der erforderlich wird, die Acer-Stämme bis zu 5 Grad (Verankerung) nach entweder ein, zwei oder drei Jahren nach der Auspflanzung ins Freiland zu biegen. Im Gegensatz dazu war die Verankerung im zweiten Jahr nach der Pflanzung von Quercus, die nicht beschnitten waren, grösser. Eine Rotation der Bäume um 180 Grad zu ihrer ursprünglichen Ausrichtung bei der Verpflanzung hatte keinen Einfluss auf die Verankerung von Acer oder Quercus. Eine Rotation der Eichen (nicht Ahorn) um180 Grad bei der Verpflanzung vergrösserte den Wurzelquerschnitt auf der Sonnenseite (Süden) des Wurzelballens, wenn die Bäume bei der Pflanzung gedreht wurden.

Resumen. La poda de raíz mediante el rasurado de cepellones en contenedor de $12 \mathrm{~L}$, cuando se cambian a contenedores de $51 \mathrm{~L}$, no tuvo impacto en la arquitectura de las raíces en Acer rubrum L. o Quercus virginiana Mill. en los $12 \mathrm{~cm}$ superiores de los cepellones de 51 L plantados, cinco años más tarde. A pesar de que las marcadas diferencias en la plantación no tuvieron impacto en la altura del árbol o el incremento en diámetro del tronco. La poda de raíces en el vivero no afectó la flexión requerida para inclinar los troncos de Acer hasta cinco grados (anclaje), ya sea uno, dos o tres años después de la plantación. Por el contrario, el anclaje fue mayor el segundo año después de la plantación de Quercus que fueron podados de raíz. La rotación de 180 grados en la plantación de su orientación en el vivero no tuvo impacto en el anclaje de Acer o Quercus, la altura del árbol o el diámetro del tronco. La rotación de árboles de encino (no de arce), en 180 grados en la plantación aumentó el área de la sección transversal de la raíz creciendo desde el lado caliente (sur) de la bola de la raíz cuando los árboles se hicieron girar durante la plantación. 